\title{
A Re-examination of the Validity of the Life Cycle Hypothesis (LCH): Evidence from Emerging Europe
}

\section{Mehmed Ganic}

International University of Sarajevo, Department of Economics and Management, Sarajevo, Bosnia and Herzegovina

mganic@ius.edu.ba

\section{Agim Mamuti}

Mother Teresa University, Department of Applied Economics and Entrepreneurship, Skopje, North Macedonia

agim.mamuti@unt.edu.mk
CroEconsur

Vol. 22

No. 2

December 2020

pp. 73-99

Received: November 2, 2020

Accepted: November 27, 2020

Research Article

doi:10.15179/ces.22.2.3

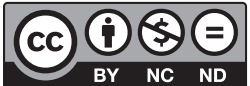

\section{Abstract}

The study aims to empirically explore the dependence of savings behavior on demographic changes in the context of the life cycle hypothesis (LCH) in a sample of 18 European transition and post-transition countries. The empirical methodology is based on a multifactor modeling approach. The research estimates heterogeneous panel data models by employing three different heterogeneous coefficient estimators: mean group (MG) estimator, common correlated effects mean group (CCEMG) estimator, and augmented mean group (AMG) estimator. The findings demonstrate that the LCH is confirmed in the case of European post-transition countries and rejected as inappropriate in European transition countries due to inconsistency of regression coefficients (age dependency, unemployment rate, urbanization, and health expenditure). The models and 
their findings presented in this study can be used in policymaking to predict dynamic interactions and variations among selected demographic variables in the determination of savings behavior.

Keywords: age dependency, savings behavior, the life cycle theory, emerging Europe, dynamic heterogeneous panel data models

JEL classification: O16, P20, J10

\section{Introduction}

The question of demographic changes has been at the forefront of the recent economic debate. This fact is well-established by the existing literature (Worthington \& Britton, 2006; Kelley \& Schmidt, 2005). Aging of the world's populations and decelerating of demographic growth followed by declines in working-age population are visible in advanced countries as well as in developing countries (Bjerke, 2014; Roser, Ritchie, \& Ortiz-Ospina, 2017). More specifically, this has been the case in Europe in recent years, followed by declines in workingage population. However, low fertility, massive emigration, and a rapid decline in the population become much more obvious when the region of Southeastern Europe is considered. Additionally, the armed conflicts in the Balkans and rigidity of the earlier economic system caused large-scale forced migration, both across the region and outside its borders, leading to destabilization of the social security system and change of the life model. After the devastation of war, reconstruction efforts in the region took place slowly, contributing largely to the lack of reforms. Because of all this, this study intends to provide possible insight into the relationship between savings and demographic changes. More specifically, this study aims to empirically explore the validity of the life cycle hypothesis (LCH) and its existence in a sample of 18 emerging Europe countries for a time of significant economic and demographic changes experienced by the region. 
Previous empirical studies failed to use appropriate estimation techniques to control for both parameter heterogeneity and cross-country dependence. To our knowledge, this study is the first such study done in some of the countries of the region such as Croatia, Estonia, and Montenegro, and there have been no other such studies implemented in emerging Europe, except partially a study done by Doker, Tutkmen, and Emsen (2016). But, in comparison with their study and other similar studies across Europe, the focus of this study is not on a single country. In fact, previous studies did not provide any comparison of the LCH between more successful transition countries and less successful ones. Second, this study employs superior estimation techniques (three heterogeneous panel data models) that accommodate both the slope of heterogeneity across the countries and the cross-country dependence. Third, the results of the tests employed in previous studies are highly sensitive to the time periods used in their execution, while this study employs the latest data for the region. Earlier studies also oftentimes ignore the fluid nature of savings and do not observe their change through time in relation to rigidity of the earlier economic system, forced migration, slow economic transformation, and change of the life model. This study offers evidence of the differences in the savings behavior brought upon by the major economic transition process for most European transition and posttransition countries.

\section{Literature Review}

The concept of LCH was introduced by Modigliani and Brumberg (1954) and Modigliani and Ando (1957), and it emerged from the argument of the microeconomic theory of consumer choice. It was utilized to explore savings and retirement behavior of the older population. Later on, this type of relationship was extended to the literature by Modigliani (1970). He developed and presented the model of life cycle to explore whether changes in savings rates are determined by economic growth and demographic structure. A large body of literature 
demonstrates empirical evidence about a statistically significant relationship between savings behavior and demographic determinants.

The importance of demographic variables in the determination of savings may be confirmed by the findings of recent empirical research conducted by Deaton and Paxson (1992), Bosworth and Chodorow-Reich (2006), Ozcan, Gunay, and Ertac (2003), Horioka and Wan (2007), Gani and Yasin (2010), and Amaglobeli et al. (2019). They empirically tested LCH and confirmed certain earlier findings that an increase in savings was caused by a higher rate of growth. The life cycle theory was attempted to be confirmed by a number of other empirical studies. In this context, many authors have tried to determine the importance of the age structure as a determinant of savings behavior using the following arguments: a high proportion of working-age population in any country can lead to a high rate of savings, because employers work longer and save more over their lifetimes to increase income for their post-retirement lives (Yashiro \& Oishi, 1996; Leff, 1969; Edwards, 1996; Callen \& Thimann, 1997; Cruz \& Ahmed, 2016; Amaglobeli et al., 2019).

After their retirement, these members of the population are expected to reduce savings, leading to a decrease in aggregate savings rate. However, in many empirical studies, there has not been a consistent response that confirms or rejects these theoretical assumptions. Even more, the findings obtained by using aggregate data (including cross-sectional studies) are in conflict with the results of studies done on the micro data.

Perhaps the most interesting case was studied by Borsch-Supan (2004), who examined the effectiveness of incentives for retirement savings in Europe. $\mathrm{He}$ concluded that people make decisions about savings usually when it is too late. Further, the research done by Loayza, Schmidt-Hebbel, and Serven (2000) and Zhang, Guariglia, and Dickinson (2015) provides evidence that savings rates are influenced negatively by rates of urbanization and the population age structure 
(dependency ratio of old and young people). Other explanatory determinants of savings include inflation and wealth, as well as the quality of health services.

Muradoglu and Taskin (1996) examined the theory of permanent and transitory income in a sample of thirty industrialized and developing countries between 1975 and 1989. They concluded that some determinants of savings fit well in the model of industrialized countries but they are not valid for developing countries. The authors explain the findings of their study as a consequence of a stable economic situation in industrialized countries where the proportion of dependent groups is lower compared to developing countries.

Another study conducted by Li, Zhang, and Zhang (2007) explored the effect of longevity and old age dependency in the determination of savings and growth in a sample of over 200 countries across the world between 1960 and 2004. They revealed a positive effect of longevity and a negative of old age dependency on savings behavior.

Several other studies, such as Kuijs (2006), Doker et al. (2016), Callen and Thimann (1997), demonstrated evidence regarding demographic determinants of savings in many countries across the world. Kuijs (2006) found evidence in China that savings rates are influenced significantly by certain determinants such as GDP per capita, credit to GDP ratio, real interest rate, public savings, old age dependency ratio, and share of industry in GDP, which are shown to be statistically significant. Amaglobeli et al. (2019) found a negative and statistically significant relationship between the old age dependency ratio and private savings in 80 countries across the world by confirming the predictions from the life cycle model.

Aron and Mihaescu (2014) explored the main variables of population savings in six CEE countries between 1995 and 2010. The study finds mixed results. For instance, a negative relationship was found between GDP growth and the savings rate, while for developed countries the determinants of savings do not coincide with those in transition countries and vice versa. 
The results of a research conducted for Asia-Pacific Economic Cooperation (APEC) countries between 2000 and 2013 show that GDP per capita growth, M2 as a percentage of GDP, age dependency ratio as a percentage of working-age population, rural population, and urban population positively affect the savings rate (Ariç, 2015). Similarly, Aizenman, Cheung, and Ito (2017) find that a rise in working-age population can lead countries to boost GDP per capita, increase savings, and reduce poverty.

Zhang et al. (2015) examined 31 Chinese provinces between 1995 and 2013 and found a statistically significant effect of selected demographic variables on savings behavior, while the income growth effect was not found. Also, they found the process of de-saving for the old age population, while urbanization had a lower negative effect on savings. More recently, Doker et al. (2016) investigated the demographic determinants of savings in 20 transitioning economies between 1993 and 2013 and revealed that the following variables have a positive correlation with savings rates: age dependency ratio (young, old), GDP per capita growth (annual percentage), labor force participation rate, female, and urban population. The relationship between national savings and the selected demographic variables is examined by employing a set of panel data models. From a theoretical perspective, research conducted by Ozcan et al. (2003) examined the relationship between urban population and the savings level. They found a negative relationship because a rise in urbanization impacts savings in the opposite way. A paper by Lall, Selod, and Shalizi (2006) describes the process of urbanization to a large extent as a result of migration from rural to urban areas due to expected higher incomes and better living conditions. Other researchers, such as Henderson, Storeygard, and Deichmann (2017), argue that rural-urban migration is motivated by poverty in rural areas. 


\section{Methodology}

The European post-transition countries comprising the sample include nine new members of the European Union that have implemented comprehensive and structural reforms (Bulgaria, Croatia, the Czech Republic, Estonia, Hungary, Poland, Romania, Slovakia, and Slovenia) and have successfully completed the process of political and economic transition by joining the EU. The group of European transitional countries includes less successful transition countries or "late reformers" (Albania, Azerbaijan, Belarus, Georgia, Moldova, Montenegro, North Macedonia, Serbia, and Ukraine). Data for this study are taken and sourced from the World Bank and Eurostat databases.

In the first step, the variability of key variables by country and over time is examined, and then the cross-sectional dependence is tested. The cross-sectional dependence across variables in the model is tested by employing the following tests: Breusch-Pagan LM test, Pesaran (2004) CD test, Pesaran (2004) scaled LM test, bias-corrected scaled LM test, and a test of slope homogeneity. Then, Pedroni residual cointegration test and Kao residual cointegration test are used to examine the existence of cointegration, and the econometric model is tested with different heterogeneous estimators.

The variety of econometric methods in testing the life cycle hypothesis suggests methods that provide the most reliable estimates. In fact, methods with homogeneous regression parameters provide inconsistent estimates, if in reality these coefficients are heterogeneous (Pesaran, Shin, \& Smith, 1999; Phillips \& Sul, 2003).

For these reasons, it is very important to consider methods that can encompass this heterogeneity.

The model (Equation 9) is estimated by employing three different heterogeneous coefficient estimators: mean group (MG) estimator, common correlated effects mean group (CCEMG) estimator, and augmented mean group (AMG) estimator. 
The traditional MG estimator developed by Pesaran and Smith (1995) does not impose any restrictions and allows for spatial heterogeneity of all coefficients in the long run and short run, but not cross-sectional dependence. The two other multifactor modeling estimators: CCEMG (Pesaran, 2006; Chudik \& Pesaran, 2015) and AMG (Eberhardt \& Teal, 2009; 2010; 2013; Bond \& Eberhardt, 2013) allow cross-section dependence arising from common factors to alleviate contemporaneous correlation problems.

The MG-estimator-initiated specification forms a model with the equation:

$\mathrm{y}_{\mathrm{it}}=\beta_{\mathrm{i}}+\beta_{\mathrm{i}}^{\prime} \mathrm{x}_{\mathrm{it}}+\mu_{\mathrm{it}}$

and forms the estimation:

$\widehat{\beta_{\mathrm{MG}}}=N^{-1} \sum_{\mathrm{i}=1}^{N} \widehat{\beta_{1}}$

with variance:

$\operatorname{Var} \widehat{\beta_{\mathrm{MG}}}=\frac{1}{\mathrm{~N}(\mathrm{~N}-1)} \sum_{i=1}^{N}\left(\widehat{\beta_{1}}-\bar{\beta}\right)$,

where $\widehat{\beta_{M G}}$ is the unweighted average of country-specific estimates.

Further, the parameter estimate can be obtained by exploiting the heterogeneity of regression coefficients with the CCEMG estimator (Pesaran, 2006; Chudik \& Pesaran, 2015). The CCEMG estimator represents an extension of the MG estimator, but aims to address cross-section dependence and heterogeneity. In fact, it assumes slope homogeneity and allows for different common effects coefficients across countries.

The CCEMG estimator is an extension of the MG estimator and is given by the following equation:

$y_{i t}=\beta_{i}+\beta_{i}^{\prime} x_{i t}+c_{1 i} \bar{y}_{t}+c_{2 i}^{\prime} \bar{x}_{t}+e_{i t}$,

where: 
$\beta_{\mathrm{i}}$ is an intercept, $\overline{\mathrm{y}}_{\mathrm{t}}$ represents cross-sectional averages of the dependent variables, $\overline{\mathrm{x}}_{\mathrm{t}}$ stands for cross-sectional averages of explanatory variables at time $\mathrm{t}$ that serve as proxies for the common factors $\left(\overline{\mathrm{y}}_{\mathrm{t}}=\sum_{i=1}^{N} \frac{\mathrm{y}_{\mathrm{it}}}{N}\right) \cdot \beta_{\mathrm{i}}^{\prime}$ refers to a vector of slope coefficients, $\mathrm{c}_{\mathrm{li}}$ is coefficient with time averages, whereas $\mathrm{c}_{2 \mathrm{i}}$ is approximation for heterogeneous factor loading.

The CCEMG estimator (Equation 5) is a simple average of the estimators of individual slope coefficients that are unbiased for $\beta$, as proved by Pesaran (2006). The CCEMG estimates are included because they provide robust estimates in a series of empirical tests. The CCEMG estimator can be expressed as follows:

$\widehat{\widehat{\beta_{\text {CCEEMG }}}}=N^{-1} \sum_{\mathrm{i}} \widehat{\beta_{1}}$,

where $\widehat{\beta_{\text {CCEEMG }}}$ is the country-specific estimate from the CCEMG estimator.

Additionally, Eberhardt and Teal (2009; 2010; 2013), Eberhardt and Bond (2009), and Bond and Eberhardt (2013) proposed the AMG method, based on Pesaran's (2006) CCE methods (CCEMG and CCEP estimators) to account for slope homogeneity and cross-sectional dependence. The AMG model aims to estimate heterogeneous regression parameters and heterogeneous factor loading, and serves as a highly robust calculation tool.

Thus, the AMG method is implemented in a two-stage procedure: in the first stage, the AMG model combines unobserved common factors with time dummies, as shown in the equation below:

$$
\Delta \mathrm{y}_{\mathrm{it}}=\beta^{\prime}+\Delta \mathrm{x}_{\mathrm{it}}+\sum_{\mathrm{t}=2}^{\mathrm{T}} \mathrm{c}_{\mathrm{t}} \Delta \mathrm{D}_{\mathrm{t}}+\mathrm{e}_{\mathrm{it}},
$$

where $D_{t}$ is the time dummy variable in first difference with corresponding parameter vector $c_{t}$, and it is equivalent to the mean value of unobserved common factors across all countries for each period $t$.

The estimation of the model with the variable $\mu_{\mathrm{t}}^{\cdot}$ is performed by applying the CCEMG method in the second stage, as follows: 
$\mathrm{y}_{\mathrm{it}}=\beta_{\mathrm{i}}+\beta_{\mathrm{i}}^{\prime} \mathrm{x}_{\mathrm{it}}+\mathrm{c}_{\mathrm{il}} t+\mathrm{d}_{\mathrm{i}}^{\prime} \mu_{\mathrm{t}}^{\cdot}+\mathrm{e}_{\mathrm{it}}$,

where $\mathrm{d}_{\mathrm{i}}$ is heterogeneous factor loading, and $\mathrm{t}$ denotes a linear trend that is included to encompass possible time effects.

The subsequent equation can be expressed in the following form:

$\widehat{\beta_{\mathrm{AMG}}}=N^{-1} \sum_{\mathrm{i}} \widehat{\beta_{1}}$.

Then, as for the MG and CCEMG, the group-specific AMG estimates are averaged across the panel.

The methodology used in this study is a modified version of the models developed initially by previous studies in examination of a life cycle model. This study uses a variant of a life cycle model introduced initially by Modigliani (1990) and Jappelli and Pagano (1994). Later, this model was adopted in studies by Sarantis and Stewart (2000), Horioka and Wan (2007), and others.

Finally, our research estimates heterogeneous panel data models in a specification as follows:

$\mathrm{GNSAV}_{\mathrm{it}}=\alpha_{\mathrm{it}}+\beta_{1} A D P_{\mathrm{i}, \mathrm{t}}+\beta_{2} \mathrm{URBAN}_{\mathrm{i}, \mathrm{t}}+\beta_{3} \mathrm{HCEXP}_{\mathrm{i}, \mathrm{t}}+\beta_{4} \mathrm{UNEMP}_{\mathrm{i}, \mathrm{t}}+\varepsilon_{\mathrm{it}}$,

where $i$ indexes the selected countries from 1 to 18 and $t$ indexes years from 2000 to 2018. $\mathrm{GNSAV}_{\mathrm{i}, \mathrm{t}}$ (gross national savings as percentage of GDP) denotes the value of the dependent variable and is often used as a proxy for testing the presence of $\mathrm{LCH}, \alpha$ is constant, while the set of explanatory variables (ADP, URBAN, HCEXP, and UNEMP) for country $i$ in year $t, \varepsilon_{\mathrm{it}}$, is the usual error term for country $i$ in year $t$ and the assumption is that $\varepsilon_{i t} \sim \operatorname{IID}\left(0, \sigma^{2} \varepsilon\right)$.

Long-run equilibrium between demographic development and savings behavior is estimated with the MG method, whereas deeper levels of the relationship are estimated by using the CCEMG and AMG methods. The literature suggests that the variables used in our models are selected because they seem like a good predictor of savings. 
In this respect, inclusion of the age dependency ratio (population aged 0-19 and 60 and more to population aged between 20 and 59) is based on evidence provided by many researchers that suggests that a decrease in age dependency ratios causes an increase in savings and vice versa (Modigliani, 1970; Yashiro \& Oishi, 1996; Gani \& Yasin, 2010; Ariç, 2015; Cruz \& Ahmed, 2016). On the other hand, several other empirical studies (Goldberger, 1973; Ram, 1984; Li et al., 2007) have rejected dependency hypotheses (i.e., the effect of age dependency on savings is found to be insignificant). It is widely understood that people save during the second halves of their working careers, to afford the education of their children and for retirement. In fact, young people save less than older workers, while the retired population spends the money saved.

Further, to improve the model, additional variables of health expenditure (health expenditure per capita) and urbanization (urban population, percentage of total) are included because they have been found to be very closely associated with demographic development. The aim of adding these two variables is to improve the "traditional model" and to get new knowledge about demographic development.

A variable of urbanization is also included because the theoretical background suggests that more people continue to internally migrate from rural areas to urban areas, and that urbanization generally decreases the precautionary motive for savings. In accordance with previous literature (Loayza et al., 2000; Ozcan et al., 2003; Zhang et al., 2015; Gök, 2014), it is assumed that a rise in urbanization negatively impacts savings. The next explanatory variable included in the model is unemployment as a share of unemployed people in the total labor force (UNEMP). It is assumed that a rise in unemployment leads to lower savings because it makes saving less affordable (Callen \& Thimann, 1997; Doker et al., 2016; Amaglobeli et al., 2019).

Health expenditure is represented by current health expenditure per capita and is expected to have a significant impact on the national savings rate. It is assumed that good health leads to higher future earnings capacity and facilitates savings 
(Smith, 1999). Also, Attanasio, Bonfatti, Kitao, and Weber (2016) believe that improvement in health quality leads to a rise in longevity and improvement in life expectancy. There is evidence that poor population health is associated with lower savings rates and vice versa (Ruger, Jamison, Bloom, \& Canning, 2006). In addition, there is a good bulk of evidence confirming that increased health expenditures exert a negative impact on savings (Arndt \& Lewis, 2000; Haacker, 2002; Cuddington, 1993; Aizenman et al., 2017). Consequently, it can be expected that richer households/companies ceteris paribus have a higher rate of savings. Since good health leads to an increase in future earnings capacity, it is reasonable to assume that economic growth by itself leads to an increase in the savings rate.

\section{Findings and Discussion}

The validity of the models was inspected using several different diagnostic tests, including testing the cross-sectional dependence, examining the stationarity of the data, and examining evidence about a long-run relationship between the explanatory variables. The cross-sectional dependence across the variables in the model was firstly tested by employing three different tests: Breusch-Pagan Lagrange multiplier (LM) test, Pesaran (2004) cross-sectional dependence (CD) test, and Pesaran (2004) scaled Lagrange multiplier (LM) test. As shown in Table 1 , the null hypothesis of cross-sectional dependence is rejected for all variables at the 1 percent level of statistical significance. Additionally, the outcomes of examining the null hypothesis of homogenous slopes indicate its rejection for all the variables. The test implies that the slope heterogeneity issue is detected or it confirms cross-country heterogeneity (Table 1). 
Table 1: Results of Testing Cross-Sectional Dependence and Slope Homogeneity

\begin{tabular}{|c|c|c|c|c|c|c|}
\hline & \multicolumn{4}{|c|}{$\begin{array}{c}\text { Cross-sectional dependence } \\
\text { test results }\end{array}$} & \multicolumn{2}{|c|}{$\begin{array}{c}\text { Slope homogeneity test } \\
\text { results }\end{array}$} \\
\hline & $\begin{array}{c}\text { LM- } \\
\text { Lagrange } \\
\text { multiplier } \\
\text { test }\end{array}$ & $\underset{\text { test }}{\text { Pesaran } C D}$ & $\begin{array}{c}\text { Bias- } \\
\text { corrected } \\
\text { scaled LM } \\
\text { test }\end{array}$ & $\begin{array}{c}\text { Pesaran } \\
\text { scaled LM } \\
\text { test }\end{array}$ & $\Delta$ & $\widehat{\Delta}_{a d j}$ \\
\hline GNSAV & $585.90^{* * *}$ & $24.75^{* * *}$ & $24.25^{* * *}$ & $4.86^{* * *}$ & $9.99^{* * *}$ & $12.08^{* * *}$ \\
\hline ADP & $1318.3^{* * *}$ & $66.62^{* * *}$ & $66.12^{* * *}$ & $24.72^{* * *}$ & $9.47^{* * *}$ & $10.31^{* * *}$ \\
\hline URBAN & $2066.2^{* * *}$ & $109.37^{* * *}$ & $108.87^{* * *}$ & $7.53^{* * *}$ & $14.50^{* * *}$ & $15.80^{* * *}$ \\
\hline UNEMP & $769.90^{* * *}$ & $35.26^{* * *}$ & $34.76^{* * *}$ & $16.48^{* * *}$ & $2.80^{* * *}$ & $3.05^{* * *}$ \\
\hline HCEXP & $2439.1^{* * *}$ & $130.68^{* * *}$ & $130.18^{* * *}$ & $49.28^{* * *}$ & $12.3^{* * *}$ & $13.45^{* * *}$ \\
\hline
\end{tabular}

Note: *, ${ }^{* *}$ and ${ }^{* * *}$ denote 10 percent, 5 percent and 1 percent significance, respectively.

Source: Authors' calculations.

Four different panel unit root tests (Levin, Lin, and Chu; Im, Pasaran, and Shin W-stat; ADF Fisher chi-square; and PP Fisher chi-square) have been utilized with the aim of examining the stationarity of the data and the order of integration of each variable. The tests suggest that the observed variables are found to be integrated at $\mathrm{I}(1)$ at the level of significance of 10 percent, 5 percent, and 1 percent at first difference (Table 2).

Table 2: Unit Root Tests

\begin{tabular}{|c|c|c|c|c|}
\hline \multirow{2}{*}{$\begin{array}{l}\text { Test } \\
\text { variable }\end{array}$} & \multicolumn{4}{|c|}{ Unit root tests } \\
\hline & $\begin{array}{l}\text { Im, Pesaran, and } \\
\text { Shin W-stat }\end{array}$ & $\begin{array}{l}\text { ADF Fisher } \\
\text { chi-square }\end{array}$ & $\begin{array}{l}\text { PP Fisher } \\
\text { chi-square }\end{array}$ & $\begin{array}{c}\text { Levin, Lin, and } \\
\text { Chu }\end{array}$ \\
\hline \multicolumn{5}{|c|}{ Panel A: Full sample estimates (first difference) } \\
\hline GNSAV & $-7.70831^{* * *}$ & $123.373^{* * *}$ & $195.351^{* * *}$ & $-8.5838^{* * *}$ \\
\hline $\mathrm{ADP}$ & $-6.63111^{* * *}$ & $102.859^{* * *}$ & $61.8193^{* * *}$ & $-7.7298^{* *}$ \\
\hline URBAN & $-4.7822^{* * *}$ & $97.6187^{* * *}$ & $63.0799^{* * *}$ & $-7.33997^{* *}$ \\
\hline UNEMP & $-8.20043^{* * *}$ & $134.161^{* * *}$ & $139.434^{* * *}$ & $-9.5633^{* * *}$ \\
\hline HCEXP & $-7.52514^{* * *}$ & $128.429^{* * *}$ & $219.338^{* * *}$ & $-10.934^{* * *}$ \\
\hline \multicolumn{5}{|c|}{ Panel B: European post-transition countries estimates (first difference) } \\
\hline GNSAV & $-5.33851^{* * *}$ & $62.0195^{* * *}$ & $92.7221^{* * *}$ & $-5.30349^{* * *}$ \\
\hline $\mathrm{ADP}$ & $-1.91670^{* *}$ & $30.2246^{* *}$ & $30.5795^{* *}$ & $-2.50758^{* * *}$ \\
\hline URBAN & $-1.68663^{* *}$ & $29.3794^{* *}$ & $36.3629^{* * *}$ & $-2.37854^{* * *}$ \\
\hline UNEMP & $-1.62379^{* *}$ & $26.5903^{*}$ & $41.7963^{* * *}$ & $-1.68348^{* *}$ \\
\hline HCEXP & $-4.76870^{* * *}$ & $54.0409^{* * *}$ & $102.594^{* * *}$ & $-6.58997^{* * *}$ \\
\hline
\end{tabular}




\begin{tabular}{|c|c|c|c|c|}
\hline \multicolumn{5}{|c|}{ Panel C: European transition countries estimates (first difference) } \\
\hline GNSAV & $-5.52556^{* * *}$ & $63.8483^{* * *}$ & $172.190^{* * *}$ & $-3.96137^{* * *}$ \\
\hline ADP & $-1.88637^{* *}$ & $31.6790^{* *}$ & $32.8081^{* *}$ & $-3.36209^{* * *}$ \\
\hline URBAN & $-3.33036^{* * *}$ & $51.1295^{* * *}$ & $31.3353^{* *}$ & $-5.78179^{* * *}$ \\
\hline UNEMP & $-6.42686^{* * *}$ & $72.8353^{* * *}$ & $73.8560^{* * *}$ & $-7.62188^{* * *}$ \\
\hline HCEXP & $-5.25266^{* * *}$ & $62.5699 * * *$ & $96.4786^{* * *}$ & $-7.38822^{* * *}$ \\
\hline
\end{tabular}

Note: *, ** and ${ }^{* * *}$ denote 10 percent, 5 percent and 1 percent significance, respectively.

Source: Authors' calculations.

Additionally, the long-run relationship between the variables was tested by employing two panel cointegration tests. Pedroni residual cointegration test (Pedroni, 1999) and Kao residual cointegration test (Kao, 1999) were applied to verify the stationarity of the residuals and estimate the parameters of the long-run relationship within the variables (Table 3).

The results of both tests indicate the existence of strong evidence about a longrun relationship between the explanatory variables (ADP, URBAN, UNEMP, and HCEXP) and GNSAV in all three panels because the ADF-statistic and PPstatistic probability values have a less than 5 percent level of significance.

Table 3: Panel Cointegration Tests Results

\begin{tabular}{|c|c|c|c|c|c|}
\hline & & & Panel A & Panel B & Panel C \\
\hline Test & $\begin{array}{c}\text { Null } \\
\text { bypothesis }\end{array}$ & $\begin{array}{c}\text { Name of the } \\
\text { statistic }\end{array}$ & \multicolumn{3}{|c|}{ t-statistic/(p-value $)$} \\
\hline \multirow{8}{*}{$\begin{array}{l}\text { Pedroni } \\
\text { residual } \\
\text { cointegration } \\
\text { test }\end{array}$} & \multirow{8}{*}{$\begin{array}{l}\text { No } \\
\text { cointegration }\end{array}$} & \multirow{2}{*}{$\begin{array}{l}\text { Panel ADF- } \\
\text { statistic }\end{array}$} & -2.77051 & -3.01484 & -1.363187 \\
\hline & & & $(-0.0028)$ & $(0.0013)$ & $(0.0864)$ \\
\hline & & \multirow{2}{*}{$\begin{array}{l}\text { Group ADF- } \\
\text { statistic }\end{array}$} & -5.935489 & -3.59816 & -3.067206 \\
\hline & & & $(0.0000)$ & $(0.0002)$ & $(0.0011)$ \\
\hline & & \multirow{2}{*}{$\begin{array}{l}\text { Panel PP- } \\
\text { statistic }\end{array}$} & -2.34023 & -1.81310 & -1.869722 \\
\hline & & & $(-0.0096)$ & $(0.0349)$ & $(0.0308)$ \\
\hline & & \multirow{2}{*}{$\begin{array}{l}\text { Group PP- } \\
\text { statistic }\end{array}$} & -5.935489 & -2.89582 & -6.005418 \\
\hline & & & $(0.0000)$ & $(0.0019)$ & $(0.0000)$ \\
\hline \multirow{2}{*}{$\begin{array}{l}\text { Kao residual } \\
\text { cointegration } \\
\text { test }\end{array}$} & \multirow{2}{*}{$\begin{array}{l}\text { No } \\
\text { cointegration }\end{array}$} & \multirow{2}{*}{$\begin{array}{l}\text { Panel ADF- } \\
\text { statistic }\end{array}$} & -3.45115 & -3.16291 & -2.817283 \\
\hline & & & $(-0.0003)$ & $(0.0008)$ & $(0.0024)$ \\
\hline
\end{tabular}

Source: Authors' calculations. 
Furthermore, the efficiency of LCH was examined within heterogeneous nonstationary dependent panels (MG estimator), as both heterogeneity and crosssectional dependence estimates (CCEMG and AMG estimators). The model estimates parameters and conducts diagnostic tests, in order to determine the methods that ensure accuracy of results when measuring the impact of demographic development on savings behavior.

As shown in Table 4, the variables ADP and HCEXP are statistically significant at the 1 percent level of significance, UNEMP at the 5 percent level of significance, and URBAN at the 10 percent level of significance in panel B measured by the AMG estimator.

Table 4: Long-Run Estimation

\begin{tabular}{|c|c|c|c|c|c|c|}
\hline \multirow[b]{2}{*}{$\begin{array}{l}\text { Explanatory } \\
\text { variables }\end{array}$} & \multicolumn{2}{|c|}{ AMG estimator } & \multicolumn{2}{|c|}{ MG estimator } & \multicolumn{2}{|c|}{ CCEMG estimator } \\
\hline & $\begin{array}{l}\text { European } \\
\text { transition } \\
\text { countries }\end{array}$ & $\begin{array}{c}\text { European } \\
\text { post- } \\
\text { transition } \\
\text { countries }\end{array}$ & $\begin{array}{l}\text { European } \\
\text { transition } \\
\text { countries }\end{array}$ & $\begin{array}{l}\text { European } \\
\text { post- } \\
\text { transition } \\
\text { countries }\end{array}$ & $\begin{array}{l}\text { European } \\
\text { transition } \\
\text { countries }\end{array}$ & $\begin{array}{c}\text { European } \\
\text { post- } \\
\text { transition } \\
\text { countries }\end{array}$ \\
\hline \multirow{2}{*}{ ADP } & -1.5979 & -.406100 & -.11946 & -.319696 & -.69835 & -.048231 \\
\hline & $(-1.30)$ & $(-2.8)^{* * *}$ & $(-0.15)$ & $(-2.34)^{* *}$ & $(-0.50)$ & $(-0.11)$ \\
\hline \multirow{2}{*}{ URBAN } & 24.5037 & -2.42280 & 8.2797 & -1.35333 & 14.8018 & -3.023941 \\
\hline & $(1.03)$ & $(-1.68)^{*}$ & $(0.95)$ & $(-0.74)$ & $(1.24)$ & $(-1.25)$ \\
\hline \multirow{2}{*}{ HCEXP } & -.01379 & -.007518 & -.00518 & -.008877 & .007817 & -.010498 \\
\hline & $(-0.82)$ & $(-5.94)^{* * *}$ & $(-0.29)$ & $(-5.20)^{* * *}$ & $(0.27)$ & $(-2.36)^{* *}$ \\
\hline \multirow{2}{*}{ UNEMP } & -2.5856 & -.33888 & .03600 & -.471956 & .059504 & .0737297 \\
\hline & $(-0.86)$ & $(-2.59)^{* *}$ & $(0.06)$ & $(-3.32)^{* * *}$ & $(0.12)$ & $(0.44)$ \\
\hline
\end{tabular}

Note: ${ }^{*}{ }^{* *}$ and ${ }^{* *}$ denote 10 percent, 5 percent and 1 percent significance, respectively. The $\mathrm{t}$-statistics are shown in parentheses.

Source: Authors' calculations.

However, the variable UNEMP does not have the expected sign according to the existing empirical evidence. This can be explained by differences in the degree of economic development, the transition process, and demographic trends that exist between the two panels of countries that have affected the overall panel. This is in line with the findings of Muradoglu and Taskin (1996), who explained the differences between industrialized and developing countries. 
However, the findings presented here for European transition countries divert from the results obtained by recent empirical studies. For instance, all employed variables (ADP, UNEMP, URBAN, and HCEXP) are shown to have a statistically insignificant impact on national savings. Although ADP, a key variable, has the expected sign, in the AMG estimates it is shown as statistically insignificant. Taking into consideration the results for European transition countries, they are contrary to what the life cycle model predicts. In fact, they indicate that the LCH does not hold for all three estimators in the case of European transition countries, making the overall LCH inefficient. The main conclusion that can be derived from examining LCH in European transition countries is that the high unemployment rate in many of the European transition countries puts pressure on relatively rigid labor markets and affects the lowering of wages and a lower rate of savings.

When examining European post-transition countries, the results are slightly different. For instance, there is a statistically significant long-run relationship between ADP and savings in the AMG and MG estimates with significance at the 1 percent and 5 percent level, respectively, with the exception of the CCEMG estimates. This especially holds true for the AMG and MG estimates, where the variables have a statistically significant impact on savings behavior. This is in line with some previous studies related to standard life cycle models conducted by Modigliani (1970), Ozcan et al. (2003), Horioka and Wan (2007), Loayza et al. (2000), Yashiro and Oishi (1996), Ariç (2015), and Cruz and Ahmed (2016). However, there is little evidence of the same variables in the CCEMG estimates because the variable of health expenditure is only shown as statistically significant. Moreover, in line with Callen and Thimann (1997), Doker et al. (2016), Li et al. (2007), Bloom, Canning, and Günther (2008), Zhang et al. (2015), Gök (2014), Ruger et al. (2006), Aizenman et al. (2017), and others, our findings confirm that the variables health expenditure and unemployment are statistically significant at the 1 percent and 5 percent level, respectively, while urbanization is statistically significant at the 10 percent level in the AMG model in EU 
post-transition countries. Specifically, the findings suggest that there is a decrease in ADP, URBAN, and UNEMP by 0.406 percent, 2.422 percent, and 0.338 percent, respectively, if gross national savings increase by 1 percent. This indicates that a higher non-working ratio in the total population leads to a lower national savings ratio. Also, it seems that the health expenditure variable is important in the determination of gross national savings in the long run. A negative sign can be explained by Ruger et al. (2006) and Aizenman et al. (2017), where poor population health is associated with lower savings rates and vice versa. However, the AMG, MG, and CCEMG estimates of the health expenditure coefficient are weak: 0.0075 percent, 0.0088 percent, and 0.010 percent, respectively. This indicates that health expenditure decreases by about $0.0075-0.010$ percent when gross national savings increase by 1 percent. The findings obtained by the AMG estimates are relevant because they serve as a robustness check of the CCEMG estimator. The age dependency variable has a negative sign and expected impact on savings behavior. This is consistent with the above-mentioned existing empirical evidence. The variable URBAN is found to have a negative correlation with national savings at the 10 percent level of statistical significance only in the AMG estimates, but not in either the CCEMG or the MG estimates.

The results of the empirical analysis presented here largely confirm earlier findings, but also reveal some new evidence contrary to previously conducted empirical studies. The results indicate that the AMG and MG estimators are considered preferable in the sample of European post-transition countries. Both estimators imply heterogeneity of regression coefficients and dynamic correlation effect, which is extremely important when measuring the impact of demographic development on savings behavior. Furthermore, the findings reveal that dividing the countries into European transition and European post-transition countries when examining the validity of the LCH is relevant. This indicates that there are greater similarities between European transition and European post-transition countries within the groups than between individual countries. The findings of the models with heterogeneous regression parameters indicate that unemployment, 
urbanization, age dependency, and health expenditure are statistically significant variables with the expected signs of regression coefficients in explaining savings behavior only in European post-transition countries, but not in European transition countries.

\section{Conclusion}

In comparison to previous empirical research, this study uses a set of different proxy variables to measure the validity of the life cycle theory and the relationship between selected demographic variables and savings behavior. The specificity of the emerging Europe countries may be explained by certain institutional changes that they experienced. These changes were particularly pronounced among the countries involved in the European integration processes. Having in mind that the transitioning countries went through a similar process of reform, and yet have had different economic achievements, the study examined whether the differences in the levels of savings in those countries have been caused by demographic determinants. The countries included in the panel are pooled by two regions: European post-transition countries and European transition countries. The efficiency of LCH was examined within heterogeneous non-stationary dependent panels (MG estimator), as both heterogeneity and cross-sectional dependence estimates (CCEMG and AMG estimators). More specifically, the study empirically explored the existence of a relationship between determinants related to age dependency and savings behavior using the life cycle theory as a model for a time of significant economic and demographic changes experienced by emerging Europe.

The findings provide insight into the effects that slow economic transformation and change of the life model had on the European transition and post-transition countries. The results also demonstrate a unique and particularly interesting dynamic between the degree of economic development, transition process, and demographic trends in the determination of gross national savings. However, 
some selected explanatory variables do not have the expected signs and are not in line with the existing empirical evidence in European transition countries. To summarize our main research results: this study found some reservations about the validity of the life cycle hypothesis in European transition countries. In fact, the hypothesis regarding the life cycle model is rejected as inconsistent with the predictions from the life cycle model. In addition, some countries from the region are among the poorest countries in Europe (Albania, Georgia, Moldova, North Macedonia, and Serbia), faced with many economic difficulties, including lack of income earning opportunities, high unemployment rates, and negative demographic trends. Having in mind that the European post-transition countries went through a similar process of reform, and yet have had different economic achievements, the differences in the levels of savings in those countries might be explained by a change in economic and demographic determinants. The study finds that these determinants matter. In fact, there is evidence that a higher working ratio in the total population, better employment environment, urbanization, and higher current health expenditure per capita in European post-transition countries lead to a rise in the national savings ratio. Accordingly, policymakers in European transition countries need to create more jobs and a better employment environment, increase the urbanization level, and include more working-age population in the total population by providing savings incentives. 


\section{Appendix 1: Definition and sources of dependent and independent variables}

\begin{tabular}{|c|c|c|}
\hline Variable & Explanation & Sources \\
\hline $\begin{array}{l}\text { Gross national } \\
\text { savings (GNSAV) }\end{array}$ & $\begin{array}{l}\text { Gross national savings as } \\
\% \text { of GDP }\end{array}$ & $\begin{array}{l}\text { World Development Indicators, World Bank } \\
\text { database (http://data.worldbank.org/data- } \\
\text { catalog/world-development-indicators) }\end{array}$ \\
\hline $\begin{array}{l}\text { Unemployment } \\
\text { (UNEMP) }\end{array}$ & $\begin{array}{l}\text { Unemployment, total } \\
\text { (\% of total labor force) } \\
\text { (modeled ILO estimate) }\end{array}$ & $\begin{array}{l}\text { World Development Indicators, World Bank } \\
\text { database (http://data.worldbank.org/data- } \\
\text { catalog/world-development-indicators) }\end{array}$ \\
\hline $\begin{array}{l}\text { Age dependency ratio } \\
\text { (ADP) }\end{array}$ & $\begin{array}{l}\text { Age dependency ratio } \\
\text { (population aged } 0-19 \\
\text { and } 60 \text { and more to } \\
\text { population aged } 20-59 \text { ) }\end{array}$ & $\begin{array}{l}\text { Population: Structure indicators, Eurostat } \\
\text { database (https://appsso.eurostat.ec.europa.eu/ } \\
\text { nui/show.do?dataset=demo_pjanind\&lang=en) }\end{array}$ \\
\hline $\begin{array}{l}\text { Urban population } \\
\text { (URBAN) }\end{array}$ & $\begin{array}{l}\text { Urban population (\% of } \\
\text { total) }\end{array}$ & $\begin{array}{l}\text { World Development Indicators, World Bank } \\
\text { database (http://data.worldbank.org/data- } \\
\text { catalog/world-development-indicators) }\end{array}$ \\
\hline $\begin{array}{l}\text { Health expenditure } \\
\text { (HCEXP) }\end{array}$ & $\begin{array}{l}\text { Health expenditure per } \\
\text { capita }\end{array}$ & $\begin{array}{l}\text { World Development Indicators, World Bank } \\
\text { database (http://data.worldbank.org/data- } \\
\text { catalog/world-development-indicators) }\end{array}$ \\
\hline
\end{tabular}




\section{Literature}

Aizenman, J., Cheung, Y., \& Ito, H. (2017). The interest rate effect on private saving: Alternative perspectives. Asian Development Bank Institute Working Paper No. 715. doi: https://doi.org/10.3386/w22872

Amaglobeli, D., Chai, H., Dabla-Norris, E., Dybczak, K., Soto, M., \& Tieman, A. F. (2019). The future of saving: The role of pension system design in an aging world. IMF Staff Discussion Note SDN/19/001. doi: https://doi.org/10.5089/9781484388990.006

Ariç, K. H. (2015). Determinants of savings in the Middle East countries. KOSBED, 29, 23-36. Retrieved from: http://kosbed.kocaeli.edu.tr/sayi29/2.pdf

Arndt, C., \& Lewis, J. (2000). The macro implications of HIV/AIDS in South Africa: A preliminary assessment. South African Journal of Economics, 68(5), 380392. doi: https://doi.org/10.1111/j.1813-6982.2000.tb01283.x

Aron, N. I., \& Mihaescu, C. (2014). Modelling the impact of economic, demographic and social determinants on household saving rate in the former socialist countries (Central and Eastern Europe). Procedia Economics and Finance, 10, 104-113. doi: https://doi.org/10.1016/S2212-5671(14)00283-4

Attanasio, O., Bonfatti, A., Kitao, S., \& Weber, G. (2016). Global demographic trends: Consumption, saving, and international capital flows. In J. Piggott \& A. Woodland (Eds.), Handbook of the economics of population aging (Vol. 1, pp. 179235). Amsterdam: Elsevier. doi: https://doi.org/10.1016/bs.hespa.2016.09.006

Bjerke, C. (2014). The impact of demographic changes on financial markets: An empirical study of the historical relationship between age structure and real returns in the United States. (Master's thesis). Norwegian School of Economics, Bergen. Retrieved from: http://hdl.handle.net/11250/221568

Bloom, D., Canning, D., \& Günther, F. (2008). Population aging and economic growth. Commission on Growth and Development Working Paper No. 32. Washington, DC: World Bank. Retrieved from: http://hdl.handle.net/10986/28027 
Bond, S., \& Eberhardt, M. (2013). Accounting for unobserved heterogeneity in panel time series models. Nuffield College Working Paper. Oxford: University of Oxford.

Borsch-Supan, A. (2004). Mind the gap: The effectiveness of incentives to boost retirement saving in Europe. Sonderforschungsbereich 504 Publications No. 07-27. Mannheim: University of Mannheim.

Bosworth, B., \& Chodorow-Reich, G. (2006). Saving and demographic change: The global dimension. Paper presented at the 8th Annual Joint Conference of the Retirement Research Consortium, Pathways to a Secure Retirement, Washington, DC. doi: https://doi.org/10.2139/ssrn.1299702

Callen, T., \& Thimann, C. (1997). Empirical determinants of household saving: Evidence from OECD countries. IMF Working Paper No. 97/181.

doi: https://doi.org/10.5089/9781451859157.001

Chudik, A., \& Pesaran, M. H. (2015). Common correlated effects estimation of heterogeneous dynamic panel data models with weakly exogenous regressors. Journal of Econometrics, 188(2), 393-420.

doi: https://doi.org/10.1016/j.jeconom.2015.03.007

Cruz, M., \& Ahmed, S. A. (2016). On the impact of demographic change on growth, savings, and poverty. World Bank Policy Research Working Paper No. 7805. Retrieved from: https://openknowledge.worldbank.org/handle/10986/25050

Cuddington, J. (1993). Modeling the macroeconomic effects of AIDS, with an application to Tanzania. The World Bank Economic Review, 7(2), 173-189.

doi: https://doi.org/10.1093/wber/7.2.173

Deaton, A., \& Paxson, C. (1992). Patterns of aging in Thailand and Côte d'Ivoire. Topics in the economics of aging. Chicago, IL: University of Chicago Press. doi: https://doi.org/10.3386/w3436 
Doker, C., Tutkmen, A., \& Emsen, S. (2016). What are the demographic determinants of savings? An analysis on transition economies (1993-2013). Procedia Economics and Finance, 39, 275-283.

doi: https://doi.org/10.1016/S2212-5671(16)30324-0

Eberhardt, M., \& Bond, S. (2009). Cross-section dependence in nonstationary panel models: A novel estimator. MPRA Paper No. 17692.

Eberhardt, M., \& Teal, F. (2009). A common factor approach to spatial heterogeneity in agricultural productivity analysis. CSAE Working Paper WPS/2009-05. Oxford: University of Oxford, Centre for the Study of African Economies.

Eberhardt, M., \& Teal, F. (2010). Productivity analysis in global manufacturing production. Discussion Paper No. 515. Oxford: University of Oxford, Department of Economics. Retrieved from:

https://www.economics.ox.ac.uk/department-of-economics-discussion-paperseries/productivity-analysis-in-global-manufacturing-production

Eberhardt, M., \& Teal, F. (2013). Structural change and cross-country growth empirics. World Bank Policy Research Working Paper No. 6335. Retrieved from: https://ssrn.com/abstract=2206183

Edwards, S. (1996). Why are Latin America's savings rates so low? An international comparative analysis. Journal of Development Economics, 51(1), 5-44. doi: https://doi.org/10.1016/S0304-3878(96)00424-5

Eurostat. (n. d.). Population: Structure indicators [Eurostat database]. Retrieved from: https://appsso.eurostat.ec.europa.eu/nui/show.do?dataset=demo_pjanind\&lang=en

Gani, A., \& Yasin, J. (2010). Demographic structure and private savings in selected countries of the Oceania region. Savings and Development, 34(2), $253-$ 267.

Gök, A. (2014). A time series analysis of the determinants of private savings in Turkey. Afro Eurasian Studies Journal, 3(1), 5-25. 
Goldberger, A. (1973). Dependency rates and saving rates: Further comment. American Economic Review, 63(1), 232-233. Retrieved from: http://pages.stern.nyu.edu/ - wgreene/Econometrics/Goldberger-on-Leff.pdf Haacker, M. (2002). The economic consequences of HIV/AIDS in Southern Africa. IMF Working Paper No. 02/38. doi: https://doi.org/10.5089/9781451845709.001

Henderson, J. V., Storeygard, A., \& Deichmann, U. (2017). Has climate change driven urbanization in Africa? Journal of Development Economics, 124, 60-82. doi: https://doi.org/10.1016/j.jdeveco.2016.09.001

Horioka, C. Y., \& Wan, J. (2007). The determinants of household saving in China: A dynamic panel analysis of provincial data. Journal of Money, Credit and Banking, 39(8), 2077-2096. doi: https://doi.org/10.1111/j.1538-4616.2007.00099.x

Jappelli, T., \& Pagano, M. (1994). Saving, growth and liquidity constraints. Quarterly Journal of Economics, 109(1), 83-109.

doi: https://doi.org/10.2307/2118429

Kao, C. (1999). Spurious regression and residual-based tests for cointegration in panel data. Journal of Econometrics, 90(1), 1-44.

doi: https://doi.org/10.1016/S0304-4076(98)00023-2

Kelley, A., \& Schmidt, R. (2005). Evolution of recent economic-demographic modeling: A synthesis. Journal of Population Economics, 18(2), 275-300.

doi: https://doi.org/10.1007/s00148-005-0222-9

Kuijs, L. (2006). How will China's saving-investment balance evolve? World Bank Policy Research Working Paper No. 3958.

doi: https://doi.org/10.1596/1813-9450-3958

Lall, S. V., Selod, H., \& Shalizi, Z. (2006). Rural-urban migration in developing countries: A survey of theoretical predictions and empirical findings. World Bank Policy Research Working Paper No. 3915. Retrieved from: http://documents.worldbank.org/curated/en/416901468140979731/Ruralurban-migration-in-developing-countries-a-survey-of-theoretical-predictionsand-empirical-findings 
Leff, N. (1969). Dependency rates and saving rates. American Economic Review, 59(5), 886-895. Retrieved from:

http://www.jstor.org/stable/1810683?seq=1\#page_scan_tab_contents

Li, H., Zhang, J., \& Zhang, J. (2007). Effects of longevity and dependency rates on saving and growth: Evidence from a panel of cross countries. Journal of Development Economics, 84(1), 138-154.

doi: https://doi.org/10.1016/j.jdeveco.2006.10.002

Loayza, N., Schmidt-Hebbel, K., \& Serven, L. (2000). Saving in developing countries: An overview. The World Bank Economic Review, 14(3), 393-414. doi: https://doi.org/10.1093/wber/14.3.393

Modigliani, F. (1970). The life-cycle hypothesis and intercountry differences in the saving ratio. In W. A. Eltis, M. F. Scott, \& J. N. Wolfe (Eds.), Induction, growth, and trade: Essays in honour of Sir Roy Harrod (pp. 197-225). Oxford: Oxford University Press.

Modigliani, F. (1990, August). Recent development in saving rates: A life cycle perspective. Frisch Lecture, Sixth World Congress of the Econometric Society, Barcelona.

Modigliani, F., \& Ando, A. (1957). Tests of the life-cycle hypothesis of savings. Oxford Bulletin of Economics and Statistics, 19(2), 99-124. doi: https://doi.org/10.1111/j.1468-0084.1957.mp19002002.x

Modigliani, F., \& Brumberg, R. (1954). Utility analysis and the consumption function. In K. Kurihara (Ed.), Post-Keynesian economics (pp. 338-436). New Brunswick, NJ: Rutgers University Press.

Muradoglu, G., \& Taskin, F. (1996). Differences in household savings behavior: Evidence from industrial and developing countries. The Developing Economies, 34(2), 138-153. doi: https://doi.org/10.1111/j.1746-1049.1996.tb00734.x

Ozcan, K., Gunay, A., \& Ertac, S. (2003). Determinants of private savings behaviour in Turkey. Applied Economics, 35(12), 1405-1416. doi: https://doi.org/10.1080/0003684032000100373 
Pedroni, P. (1999). Critical values for cointegration tests in heterogeneous panels with multiple regressors. Oxford Bulletin of Economics and Statistics, 61(S1), 653670 .

Pesaran, M. H. (2004). General diagnostic tests for cross section dependence in panels. Cambridge Working Papers in Economics No. 0435.

Pesaran, M. H. (2006). Estimation and inference in large heterogeneous panels with multifactor error structure. Econometrica, 74(4), 967-1012.

Pesaran, M. H., Shin, Y., \& Smith, R. P. (1999). Pooled mean group estimation of dynamic heterogeneous panels. Journal of the American Statistical Association, 94(446), 621-634. doi: https://doi.org/10.1080/01621459.1999.10474156

Pesaran, M. H., \& Smith, R. P. (1995). Estimating long-run relationships from dynamic heterogeneous panels. Journal of Econometrics 68(1), 79-113.

doi: https://doi.org/10.1016/0304-4076(94)01644-F

Phillips, P. C. B., \& Sul, D. (2003). Dynamic panel estimation and homogeneity testing under cross section dependence. The Econometrics Journal, 6(1), 217-259. doi: https://doi.org/10.1111/1368-423X.00108

Ram, R. (1984). Dependency rates and savings: Reply. American Economic Review, 74(1), 234-237.

Roser, M., Ritchie, H., \& Ortiz-Ospina, E. (2017). World population growth. Our World in Data. Retrieved from: https://ourworldindata.org/world-population-growth

Ruger, J., Jamison, D., Bloom, D., \& Canning, D. (2006). Health and the economy. In M. H. Merson, R. E. Black, \& A. J. Mills (Eds.), Global health: Diseases, programs, systems, and policies (pp. 757-802). Sudbury, MA: Jones \& Bartlett Learning.

Sarantis, N., \& Stewart, C. (2000, September). Saving behaviour in OECD countries: Evidence from panel cointegration tests. Paper presented at the Money, Macro and Finance Research Group Annual Conference, South Bank University, London. 
Smith, J. P. (1999). Healthy bodies and thick wallets: The dual relation between health and economic status. Journal of Economic Perspectives, 13(2), 145-166. doi: https://doi.org/10.1257/jep.13.2.145

World Bank. (n. d.). World development indicators [World Bank database]. Retrieved from:

http://data.worldbank.org/data-catalog/world-development-indicators

Worthington, I., \& Britton, C. (2006). The business environment (5th edition). Harlow: Pearson Education Limited.

Yashiro, N., \& Oishi, A. S. (1996). Population aging and the savings-investment balance in Japan. In M. D. Hurd \& N. Yashiro (Eds.), The economic effects of aging in the United States and Japan (National Bureau of Economic Research Project Report) (pp. 59-87). Chicago, IL: University of Chicago Press. Retrieved from: http://www.nber.org/chapters/c8461.pdf

Zhang, Y., Guariglia, A., \& Dickinson, D. (2015). Old-age dependency and household finance (Working Paper, Department of Economics, University of Birmingham). Retrieved from:

http://www.birmingham.ac.uk/Documents/college-social-sciences/business/ events/mmf-workshop/posters/ZHANG-Old-Age-Dependency-and-HouseholdFinance.pdf 